\title{
Edukasi Gizi pada Ibu Hamil Mencegah Stunting pada Kelas Ibu Hamil
}

\author{
Ni Wayan Dian Ekayanthi ${ }^{1}$, Pudji Suryani ${ }^{2}$ \\ ${ }^{1}$ Program Studi Kebidanan, Politeknik Kesehatan Kemenkes Bandung, Indonesia \\ ${ }^{2}$ Program Studi Promosi Kesehatan, Politeknik Kesehatan Kemenkes Malang, Indonesia \\ Email: ekayanthi@yahoo.com
}

\begin{abstract}
Nutrition Education to Pregnant Woman Prevent Stunting in Pregnant Woman Class. Stunting reflects the existence of chronic malnutrition problems, which influenced by the condition nutrition status of the prospective mother, during pregnancy, and baby 1000 first days of life (1000 HPK) It's also influenced by health status on 1000 HPK. Stunting has a long-term adverse impact of declining cognitive ability and learning achievement decreased immunity and high risk for the emergence of diabetes, obesity, cardiovascular disease, cancer, stroke, and disability when they adults. It's will lead to poor quality of work. Improvement efforts have needed for stunting prevention through specific nutritional interventions, particularly during pregnancy. Antenatal class is one measurement that can be used to disseminate information for behavior change relating to nutrition and healthiness during pregnancy to prevent stunting. This study aims to obtain the influence of the antenatal class toward knowledge and attitude improvement on stunting prevention. Pre-experimental design (one group pre-test post-test) with a sample of 35 first trimester pregnant women without complications, which are given antenatal class three times. Data retrieved with instruments of pre and post-intervention (antenatal class). Data were analyzed using a paired t-test for the knowledge variables and the Wilcoxon test for attitudinal variables. There was a significant influence of the antenatal class toward knowledge and attitude improvement on stunting prevention ( $p$-value<0,05). The antenatal class increases pregnant women's knowledge and attitude on stunting prevention.
\end{abstract}

Keywords: Antenatal class, Attitude, Knowledge, Stunting

\begin{abstract}
Abstrak: Edukasi Gizi pada Ibu Hamil Mencegah Stunting pada Kelas Ibu Hamil. Stunting menggambarkan adanya masalah gizi kronis, dipengaruhi kondisi ibu/calon ibu, masa janin, dan bayi/balita, termasuk penyakit yang diderita selama masa balita. Dampak buruk stunting jangka panjang menurunnya kemampuan kognitif dan prestasi belajar, menurunnya kekebalan tubuh, dan risiko tinggi untuk munculnya penyakit diabetes, kegemukan, penyakit jantung dan pembuluh darah, kanker, stroke, dan disabilitas pada usia tua, serta kualitas kerja yang kurang. Upaya perbaikan yang diperlukan untuk mengatasi stunting salah satunya melalui intervensi gizi spesifik pada ibu hamil. Kelas ibu hamil merupakan salah satu cara yang dapat digunakan untuk menyebarkan informasi yang berkaitan dengan gizi dan kesehatan saat kehamilan untuk mencegah stunting. Tujuan penelitian diketahuinya pengaruh kelas ibu hamil terhadap peningkatan pengetahuan dan sikap tentang pencegahan stunting. Metode pre-experimental design (one group pre-test post-test), subjek penelitian 35 orang ibu hamil trimester I normal tanpa komplikasi, diberikan intervensi kelas ibu hamil 3 kali pertemuan. Pengambilan data dengan instrumen pre dan post test intervensi. Analisis data dengan uji paired t test untuk variabel pengetahuan dan uji Wilcoxon untuk variabel sikap. Terdapat pengaruh yang bermakna kelas ibu hamil terhadap peningkatan pengetahuan dan sikap ibu hamil tentang pencegahan stunting ( $p$-value $<0,05)$. Kelas ibu hamil meningkatan pengetahuan dan sikap ibu hamil tentang pencegahan stunting.
\end{abstract}

Kata kunci: Kelas ibu hamil, Sikap, Pengetahuan, Stunting

\section{PENDAHULUAN}

Stunting atau kurang gizi kronik adalah suatu bentuk lain dari kegagalan pertumbuhan, dan kurang gizi kronik. Keadaan yang sudah terjadi sejak lama, bukan seperti kurang gizi akut. Stunting dapat juga terjadi sebelum kelahiran dan disebabkan oleh asupan gizi yang sangat kurang saat masa kehamilan, pola asuh makan yang sangat kurang, rendahnya kualitas makanan sejalan dengan frekuensi infeksi sehingga dapat menghambat pertumbuhan (Unicef Indonesia, 2012). Persentase balita pendek menjadi masalah kesehatan masyarakat jika prevalensinya $\geq 20 \%$ 
(Pusat Data dan Informasi Kementerian Kesehatan RI, 2016).

Dampak yang dapat ditimbulkan oleh stunting dalam jangka pendek terganggunya perkembangan otak, kecerdasan, gangguan pertumbuhan fisik, dan gangguan metabolisme dalam tubuh. Dampak buruk dalam jangka panjang menurunnya kemampuan kognitif dan prestasi belajar, menurunnya kekebalan tubuh sehingga mudah sakit, dan risiko tinggi untuk munculnya penyakit diabetes, kegemukan, penyakit jantung dan pembuluh darah, kanker, stroke, dan disabilitas pada usia tua, serta kualitas kerja yang tidak kompetitif yang berakibat pada rendahnya produktivitas ekonomi (Unicef Indonesia, 2012). Anak yang stunting sebagian besar memiliki prestasi belajar kurang, sementara anak yang tidak stunting sebagian besar memiliki prestasi belajar yang baik (Picauly, 2013).

Hasil penelitian menunjukkan bahwa stunting dipengaruhi oleh faktor pendapatan keluarga, pengetahuan gizi ibu, pola asuh ibu, riwayat infeksi penyakit, riwayat imunisasi, asupan protein, dan asupan ibu. Asupan ibu terutama saat hamil merupakan salah satu faktor yang berperan penting. Gizi janin bergantung sepenuhnya pada ibu, sehingga kecukupan gizi ibu sangat memengaruhi kondisi janin yang dikandungnya. Ibu hamil yang kurang gizi atau asupan makanan kurang akan menyebabkan gangguan pertumbuhan janin dalam kandungan (Picauly, 2013).

Upaya perbaikan yang diperlukan untuk mengatasi stunting meliputi upaya untuk mencegah dan mengurangi gangguan secara langsung (intervensi gizi spesifik) dan upaya untuk mencegah dan mengurangi gangguan secara tidak langsung (intervensi gizi sensitif). Upaya intervensi gizi spesifik difokuskan pada kelompok 1.000 Hari Pertama Kehidupan (HPK), yaitu ibu hamil, ibu menyusui, dan anak 0-23 bulan, karena penanggulangan stunting yang paling efektif dilakukan pada 1.000 HPK (periode emas atau periode kritis/windows of opportunity) (Pusat Data dan Informasi Kementerian Kesehatan RI, 2016). Adanya kegagalan pertumbuhan (growth faltering) akan menyebabkan seorang anak bertubuh pendek, proses ini dimulai dari dalam rahim hingga usia dua tahun. Setelah anak melewati usia dua tahun, maka usaha untuk memperbaiki kerusakan pada tahun-tahun awal sudah terlambat. Maka dari itu, status kesehatan dan gizi ibu hamil berperan penting dalam mencegah stunting.

Perbaikan gizi dan kesehatan ibu hamil sangat terkait dengan tingkat pendidikan, pengetahuan, serta sikap dalam pemenuhan kebutuhan zat gizi selama hamil. Pengetahuan yang tidak memadai dan praktik yang tidak tepat merupakan hambatan terhadap peningkatan gizi. Pada umumnya, orang tidak menyadari pentingnya gizi selama kehamilan dan dua tahun pertama kehidupan. Perempuan sering tidak menyadari pentingnya gizi mereka sendiri (Unicef Indonesia, 2012).

Kurangnya kesadaran tentang pentingnya gizi ibu akan berdampak pada kurangnya upaya yang dilakukan untuk pencegahan stunting. Kondisi ini tentunya akan berlanjut sampai dengan anak lahir dan tumbuh. Dalam perkembangannya, anak yang bertubuh pendek dianggap wajar dan tidak berdampak untuk perkembangan anak selanjutnya sehingga tidak memerlukan penanganan khusus.

Kelas ibu hamil merupakan salah satu cara yang dapat digunakan untuk menyebarkan informasi yang berkaitan dengan gizi dan kesehatan saat kehamilan. Materi yang diberikan pada program kelas ibu hamil salah satunya tentang perawatan kehamilan, terutama dalam penyiapan dan pemenuhan gizi masa hamil (Kementerian Kesehatan RI, 2011).

Dari hasil penelitian Hastuti (2011) diperoleh bahwa terdapat pengaruh kelas ibu hamil terhadap pengetahuan dan sikap ibu dalam asuhan antenatal dengan nilai $p$-value $=0,000$ dan $p$-value $=0,017$, serta nilai OR 11,7. Hasil penelitian lain diperoleh bahwa pelatihan kelas ibu hamil efektif untuk meningkatkan pengetahuan, sikap, keterampilan, dan kunjungan ANC. Implementasi kelas ibu hamil diharapkan mampu mengubah perilaku ibu hamil dalam pemanfaatan pelayanan kesehatan, termasuk pemenuhan gizi ibu hamil dan kunjungan ibu hamil.

Promosi kesehatan berpengaruh terhadap peningkatan pengetahuan ibu hamil tentang tanda bahaya kehamilan. Hasil yang diharapkan dari pendidikan kesehatan adalah adanya peningkatan pengetahuan dan sikap dan tujuan akhir tercapainya perubahan perilaku individu, keluarga, dan masyarakat dalam memelihara perilaku sehat serta berperan aktif dalam mewujudkan derajat kesehatan yang optimal (Wenas, 2014). Pemberian pendidikan kesehatan pada ibu hamil melalui kelas ibu hamil diharapkan akan berdampak pada peningkatan pengetahuan dan kemampuan dalam penerapan kesehatan dan gizi keluarganya, sehingga nantinya anak akan berada dalam keadaan status gizi yang baik dan stunting tidak terjadi. 


\section{METODE}

Desain penelitian yang digunakan adalah pre-experimental design, yaitu one group pre-test post-test. Penelitian ini dilakukan di Wilayah Puskesmas Bogor Barat, yaitu Puskesmas Gang Kelor dan Puskesmas Sindang Barang dari bulan Juli sampai September 2017.

Populasi penelitian ini adalah seluruh ibu hamil trimester I, dengan jumlah sampel sebanyak 35 orang. Perhitungan jumlah sampel menggunakan rumus besar sampel penelitian uji hipotesis beda rata-rata 2 kelompok berpasangan. Teknik pengambilan sampel dilakukan dengan consecutive sampling. Pengumpulan data menggunakan instrumen untuk kegiatan pre dan post intervensi kelas ibu hamil. Sebelum intervensi dilakukan, diberikan instrumen pre-test untuk mengetahui kondisi awal pengetahuan dan sikap ibu hamil tentang pencegahan stunting. Selanjutnya diberikan kelas ibu hamil sebanyak 3 kali pertemuan, kemudian dilakukan pengukuran pengetahuan dan sikap ibu tentang pencegahan stunting menggunakan instrumen post-test.

Sebelum analisis, dilakukan uji normalitas data dengan uji Shapiro Wilk untuk sampel kecil $(\leq 50)$ dengan hasil data pengetahuan terdistribusi normal $(p$-value $>0,05)$ dan data sikap terdistribusi tidak normal $(p$-value $<0,05)$. Analisis data menggunakan uji paired t-test untuk data pengetahuan dan uji Wilcoxon untuk data sikap.

Penelitian ini telah mendapat persetujuan etik penelitian dari Komisi Etik Penelitian
Kesehatan Politeknik Kesehatan Kemenkes Bandung Nomor: 63/KEPK/PE/VI/2017.

\section{HASIL}

Tabel 1. Karakteristik Subjek Penelitian

\begin{tabular}{lrr}
\hline \multicolumn{1}{c}{ Karakteristik } & n & \% \\
\hline Umur (tahun) & & \\
a. <20 dan >35 & 5 & 14,3 \\
b. 20-35 tahun & 30 & 85,7 \\
Pendidikan & & \\
$\quad$ a.Pendidikan Rendah & 20 & 57,1 \\
$\quad$ (SD, SMP) & & \\
$\quad$ b.Pendidikan Tinggi & 15 & 42,9 \\
$\quad$ (SMU, PT) & & \\
Pekerjaan & & \\
$\quad$ a. Ibu rumah tangga & 33 & 94,2 \\
$\quad$ b. Wiraswasta & 1 & 2,9 \\
$\quad$ c. Lainnya (honorer) & 1 & 2,9 \\
Gravida & & \\
$\quad$ a. Multigravida & 25 & 71,4 \\
b. Primigravida & 10 & 28,6 \\
\hline
\end{tabular}

Berdasarkan tabel 1 diketahui bahwa subjek penelitian paling banyak berumur 20-35 tahun, yaitu $85,7 \%$, tingkat pendidikan ibu paling banyak pendidikan rendah sebesar $57,1 \%$, sebagian besar pekerjaan ibu adalah ibu rumah tangga 94,2\% dan ibu yang memiliki anak lebih dari 1 orang (multigravida) sebanyak 71,4\%.

Pada tabel 2 disajikan mengenai pengetahuan subjek penelitian sebelum dan setelah kelas ibu hamil.

Tabel 2. Pengetahuan Subjek Penelitian Sebelum dan Setelah Kelas Ibu Hamil

\begin{tabular}{llrrrr}
\hline Pengetahuan & n & Rerata \pm s.b & Perbedaan rerata \pm s.d & IK 95\% & $p$-value \\
\hline Pengetahuan sebelum kelas ibu hamil & 35 & $8,80 \pm 3,56$ & $5,83 \pm 3,54$ & $4,61-7,04$ & 0,000 \\
Pengetahuan setelah kelas ibu hamil & 35 & $24,63 \pm 2,46$ & & & \\
\hline
\end{tabular}

Tabel 2 menunjukkan terjadinya peningkatan rata-rata (mean) pengetahuan ibu hamil sebelum intervensi kelas ibu hamil 18,8 dan $p$-value diperoleh dari uji paired t-test dengan nilai signifikansi sebesar $0,000 \quad(p$ - value $<0,05)$ sehingga Ho ditolak, artinya terdapat peningkatan pengetahuan tentang pencegahan stunting secara signifikan sebelum dengan setelah diberikan intervensi.

Tabel 3. Sikap Subjek Penelitian Sebelum dan Setelah Kelas Ibu Hamil

\begin{tabular}{lcrrr}
\hline \multicolumn{1}{c}{ Sikap } & $\mathbf{n}$ & $\begin{array}{c}\text { Median } \\
\text { (minimun-maksimum) }\end{array}$ & Rerata \pm s.d & p-value \\
\hline Sikap sebelum kelas ibu hamil & 35 & $62(52-76)$ & $62,77 \pm 6,74$ & 0,001 \\
Sikap setelah kelas ibu hamil & 35 & $67(58-79)$ & $66,89 \pm 5,88$ & \\
\hline
\end{tabular}

Tabel 3 menunjukkan adanya peningkatan rata-rata (mean) sikap ibu hamil sebelum intervensi, yaitu 62,77 dan sesudah intervensi, yaitu 66,89 . Perbedaan standar deviasi sebelum intervensi 6,74 dan setelah intervensi 5,88. Nilai $p$-value diperoleh dari uji Wilcoxon karena data sikap tidak terdistribusi secara normal. Nilai signifikansi untuk sikap berdasarkan uji Wilcoxon sebesar 0,001 ( $p$-value $<0,05)$ sehingga Ho ditolak, artinya terdapat peningkatan sikap 
tentang pencegahan stunting secara signifikan sebelum dengan setelah diberikan intervensi.

Tabel 4. Pengaruh Kelas Ibu Hamil terhadap Pengetahuan dan Sikap tentang Pencegahan Stunting

\begin{tabular}{lrrrrr}
\hline \multirow{2}{*}{ Variabel } & \multicolumn{2}{c}{$\begin{array}{c}\text { Sebelum } \\
\text { Intervensi }\end{array}$} & \multicolumn{2}{c}{$\begin{array}{c}\text { Setelah } \\
\text { Intervensi }\end{array}$} & p-value \\
\cline { 2 - 5 } & f & \% & \multicolumn{1}{c}{ f } & \% & \\
\hline $\begin{array}{l}\text { Tingkat } \\
\text { pengetahuan }\end{array}$ & & & & & \\
a. Baik & 15 & 42,9 & 34 & 97,1 & 0,000 \\
b. Kurang & 20 & 57,1 & 1 & 2,9 & \\
\hline Total & 35 & 100 & 35 & 100 & \\
\hline Sikap & & & & & \\
a. Positif & 17 & 48,6 & 25 & 71,4 & 0,001 \\
b. Negatif & 18 & 51,4 & 10 & 28,6 & \\
\hline Total & 35 & 100 & 35 & 100 & \\
\hline
\end{tabular}

Berdasarkan tabel 4 diperoleh pengetahuan sebelum intervensi kelas ibu hamilsebagian besar terdapat pada kategori kurang $(57,1 \%)$ namun setelah pelaksanaan kelas ibu hamil terjadi peningkatan pengetahuan, yaitu sebagian besar dengan katagori baik $(97,1 \%)$. Sikap sebelum intervensi kelas ibu hamilsebagian besar terdapat pada kategori negatif $(51,4 \%)$ namun setelah pelaksanaan kelas ibu hamil terjadi peningkatan sikap, yaitu sebagian besar dengan katagori positif $(71,4 \%)$. Sesuai dengan tabel sebelumnya, nilai $p$-value untuk pengetahuan dan sikap masing-masing sebesar 0,000 dan 0,003 $(<0,005)$. Berdasarkan hal tersebut disimpulkan bahwa terdapat pengaruh yang signifikan pemberian kelas ibu hamil terhadap peningkatan pengetahuan dan sikap tentang pencegahan stunting.

\section{PEMBAHASAN}

\section{Pengaruh Kelas Ibu Hamil terhadap Pengetahuan tentang Pencegahan Stunting}

Dari hasil penelitian diketahui bahwa pelaksanaan kelas ibu hamil mempunyai pengaruh yang signifikan terhadap peningkatan pengetahuan ibu tentang pencegahan stunting. Sikap dan perilaku ibu selama hamil didukung oleh pengetahuan ibu tentang kehamilannya.

Seorang ibu yang memiliki pengetahuan dan sikap tentang gizi yang kurang akan sangat berpengaruh terhadap status gizinya, karena pengetahuan yang baik terkait dengan penyediaan pemilihan menu yang seimbang (Olsa, 2017). Status gizi ibu hamil tersebut sangat mempengaruhi keadaan kesehatan dan perkembangan janin. Gangguan pertumbuhan yang terjadi dalam kandungan dapat menyebabkan berat badan lahir rendah sehingga mempunyai risiko lebih tinggi untuk menjadi stunting (Ni'mah, 2015). Stunting merupakan masalah gizi kronis yang disebabkan oleh asupan gizi yang kurang dalam waktu cukup lama akibat pemberian makanan yang tidak sesuai dengan kebutuhan gizi (Syari, 2015).

Sejalan dengan hal tersebut, penelitian menunjukkan kejadian stunting merupakan suatu proses kumulatif sejak kehamilan. Oleh karena itu, faktor gizi ibu selama kehamilan merupakan penyebab tidak langsung yang berkontribusi terhadap pertumbuhan dan perkembangan janin. Ibu hamil dengan kondisi gizi kurang akan menyebabkan janin mengalami intrauterin growth retardation (IUGR) sehingga bayi tersebut akan lahir dengan kondisi kurang gizi dan mengalami gangguan pertumbuhan dan perkembangan. Kekurangan gizi pada usia dini meningkatkan angka kematian bayi dan anak, menyebabkan penderitanya mudah sakit, kurangnya kemampuan kognitif, dan memiliki postur tubuh yang tidak maksimal saat tumbuh dewasa.

Faktor gizi salah satunya pada ibu hamil yaitu kekurangan energi kronik (KEK), dimana seperti penelitian yang dilakukan di Madiun, diketahui ibu hamil dengan KEK mempunyai risiko 8,24 kali lebih besar melahirkan bayi dengan BBLR yang akan berdampak stunting pada anak di masa akan datang (Trihardiani, 2011). Sejalan dengan penelitian yang dilakukan oleh Sartono (2013) menunjukkan bahwa terdapat hubungan yang sifnifikan antara ibu hamil Kekurangan Energi Kronis (KEK) dengan kejadian stunting pada balita.

Kejadian stunting dapat dicegah salah satunya dengan pemenuhan kebutuhan zat gizi bagi ibu hamil. Kehamilan merupakan periode penting dalam pembentukan kualitas sumber daya manusia di masa yang akan datang. Pertumbuhan, perkembangan serta kesehatan anak sangat ditentukan oleh kondisi janin saat di dalam kandungan. Di Negara berkembang termasuk Indonesia masalah gizi masih merupakan masalah kesehatan masyarakat yang utama. Rendahnya status gizi ibu hamil selama kehamilan dapat mengakibatkan berbagai dampak tidak baik bagi ibu dan bayi (MCAI, 2016). Pemenuhan kebutuhan nutrisi ini berkaitan erat dengan tinggi rendahnya pengetahuan ibu hamil tentang gizi (Goni, 2013). Hal tersebut menunjukkan bahwa peningkatan pengetahuan ibu hamil termasuk tentang gizi sangat penting agar ibu hamil lebih memperhatikan kondisinya saat hamil terutama 
makanan yang dikonsumsi untuk mencegah kejadian stunting. Selain tentang pemenuhan gizi, ibu juga perlu mengetahui tentang bagaimana penyiapan makanan dengan benar agar zat gizi dan kebersihannya terjaga dengan baik. Selain itu, faktor sanitasi dan kebersihan lingkungan berpengaruh untuk kesehatan ibu hamil dan tumbuh kembang anak. Rendahnya sanitasi dan kebiasaan menyiapkan makanan yang salah menyebabkan asupan gizi makin rendah.

Pentingnya pengetahuan tentang gizi ibu hamil dan bagaimana menyiapkan makanan yang benar dapat diperoleh dari petugas kesehatan (bidan) saat dilakukan kelas ibu hamil. Kelas ibu hamil merupakan sarana belajar bersama tentang kesehatan bagi ibu hamil dalam bentuk tatap muka dalam kelompok yang bertujuan untuk meningkatkan pengetahuan dan keterampilan ibu mengenai kehamilan, perawatan kehamilan, persalinan, nifas, serta bayi baru lahir. Dengan adanya kelas ibu hamil, ibu dapat mengetahui tentang pengaturan gizi saat hamil yang secara langsung meningkatkan pengetahuan ibu tentang pencegahan stunting.

Hasil penelitian menunjukkan bahwa stunting dipengaruhi salah satunya oleh pengetahuan gizi ibu dan asupan ibu. Asupan ibu terutama saat hamil merupakan salah satu faktor yang berperan penting. Gizi janin bergantung sepenuhnya pada ibu, sehingga kecukupan gizi ibu sangat memengaruhi kondisi janin yang dikandungnya. Ibu hamil yang kurang gizi atau asupan makanan kurang akan menyebabkan gangguan pertumbuhan janin dalam kandungan (Picauly, 2013). Asupan makanan selama hamil berbeda dengan asupan sebelum masa kehamilan. Berdasarkan angka kecukupan gizi (AKG) diperlukan tambahan 300 kkal perhari selama kehamilan. Penambahan protein $20 \mathrm{~g} / \mathrm{hr}$; lemak 10 $\mathrm{g} / \mathrm{hr}$ dan karbohidrat $40 \mathrm{~g} / \mathrm{hr}$ selama kehamilan serta mikronutrisi lainnya untuk membantu proses pertumbuhan janin di dalam kandungan (MCAI, 2016).

Untuk pertumbuhan janin yang memadai diperlukan zat-zat makanan yang cukup dengan peran plasenta yang besar dalam transfer zat-zat makanan. Pertumbuhan janin paling pesat terjadi pada stadium akhir kehamilan sehingga dibutuhkan lebih banyak zat makanan pada stadium tersebut. Meskipun demikian, pentingnya terpenuhi juga nutrisi pada awal kehamilan (trimester I) karena pembentukan organ (organogenesis) terjadi pada periode ini. Terjadinya defisiensi nutrisi yang esensial selama trimester I dapat mengganggu pembentukan organ yang dapat berakibat cacat janin atau abortus (keguguran). Perkembangan janin melalui sejumlah periode perkembangan kritis saat terjadi organogenesis dan diferensiasi. Periode pertumbuhan, perkembangan cepat dan maturasi ini adalah tahap di mana janin rentan terhadap stressor seperti malnutrisi, gangguan penyediaan oksigen, infeksi atau gangguan lingkungan lain terjadi (Dimiati, 2012). Anakanak yang mengalami hambatan dalam pertumbuhan disebabkan kurangnya asupan makanan yang memadai dan penyakit infeksi yang berulang, dan meningkatnya kebutuhan metabolik serta mengurangi nafsu makan, sehingga meningkatnya kekurangan gizi pada anak. Keadaan ini semakin mempersulit dalam mengatasi gangguan pertumbuhan yang akhirnya berpeluang terjadinya stunting. Periode yang paling kritis dalam penanggulangan stunting dimulai sejak janin dalam kandungan sampai anak berusia 2 tahun yang disebut dengan periode emas (1000 HPK). Oleh karena itu, perbaikan gizi diprioritaskan pada usia 1000 HPK yaitu 270 hari selama kehamilannya dan 730 hari pada kehidupan pertama bayi yang dilahirkannya.

\section{Pengaruh Kelas Ibu Hamil terhadap Sikap tentang Pencegahan Stunting}

Dari hasil penelitian juga diketahui bahwa pelaksanaan kelas ibu hamil mempunyai pengaruh yang signifikan terhadap peningkatan pengetahuan ibu tentang pencegahan stunting. Faktor-faktor yang mempengaruhi sikap adalah pengalaman, informasi kesehatan yang diperoleh dari orang lain yang dianggap penting, kebudayaan, media massa, lembaga pendidikan dan lembaga agama, emosional (Azwar, 2010).

Timbulnya perilaku seseorang didasari oleh pengetahuan dan kesadaran serta sikap yang positif dari individu. Semakin tinggi pemahaman ibu hamil akan semakin baik dalam menyikapi kehamilannya (Wenas, 2014). Sikap merupakan cara seseorang melihat sesuatu secara mental dari dalam diri dan mengarah pada perilaku yang ditujukan pada orang lain, ide, objek maupun kelompok tertentu. Sikap merupakan kesiapan merespon yang sifatnya positif atau negatif terhadap suatu obyek atau situasi secara konsisten. Sikap merupakan kecenderungan bertindak dari individu berupa respons tertutup terhadap stimulus maupun obyek tertentu. Jadi sikap bukanlah suatu tindakan ataupun aktivitas, akan tetapi merupakan sebuah kecenderungan untuk melakukan tindakan atau perilaku atau peran (Olsa, 2017). Sikap tersebut berkaitan dengan penanggulangan pencegahan stunting meliputi upaya ibu dalam memperbaiki gizi ibu hamil dengan mengkonsumsi makanan yang 
baik, mengkonsumsi tablet tambah darah dan upaya menjaga kesehatanannya selama hamil sehingga terjaga dari penyakit (Dinkes Provinsi Sumatera Selatan, 2016).

Stunting disebabkan oleh multi faktor. Penyebab langsung berkaitan dengan kurangnya asupan makanan dan penyakit infeksi. Faktor lainnya adalah pengetahuan ibu yang kurang, pola asuh yang salah, sanitasi dan hygiene yang buruk dan rendahnya pelayanan kesehatan. Selain itu, masyarakat belum menyadari anak dengan kondisi pendek merupakan suatu masalah, karena anak pendek di masyarakat terlihat sebagai anakanak dengan aktivitas yang normal, tidak seperti anak kurus yang harus segera ditanggulangi. Demikian pula halnya gizi ibu sewaktu hamil, masyarakat belum menyadari pentingnya gizi selama kehamilan berkontribusi terhadap keadaan gizi bayi yang akan dilahirkannya nanti (Unicef Indonesia, 2012).

Masalah stunting di masyarakat perlu mendapat perhatian yang serius. Masih banyak masyarakat yang belum menyadari bahwa anak pendek itu merupakan masalah kesehatan, karena pada umumnya anak pendek terlihat di masyarakat sebagai anak-anak dengan aktivitas yang normal. Tidak seperti anak kurang gizi, anak pendek dapat berakibat fatal bagi produktivitas mereka di masa dewasa. Meskipun gangguan pertumbuhan fisik anak masih dapat diperbaiki di kemudian hari dengan peningkapan asupan gizi yang baik, namun tidak dengan perkembangan kecerdasannya.

Dampak stunting terhadap prestasi sekolah juga didukung oleh penelitian terhadap anak usia 6-16 tahun di Kamboja. Dari hasil penelitian ini ditemukan bahwa anak yang mengalami stunting moderate dan severe memiliki kecerdasan kognitif yang lebih rendah dibanding dengan anak yang normal (Perignon, 2014).

Untuk mencegah terjadinya stunting di usia dini, terutama pada saat lahir, maka ibu hamil perlu asupan zat gizi makro dan mikro yang cukup, karena status gizi saat lahir berpengaruh besar terhadap pertumbuhan bayi selanjutnya, terutama pada usia 2 tahun pertama kehidupan (Ernawati, 2013). Penanggulangan stunting yang efektif dilakukan pada 1000 HPK. Kejadian balita stunting dapat dicegah dan diputus mata rantainya sejak janin dalam kandungan dengan cara melakukan pemenuhan kebutuhan zat gizi bagi ibu hamil, artinya setiap ibu hamil harus mendapatkan makanan yang cukup gizi, mendapatkan suplementasi zat gizi (tablet $\mathrm{Fe}$ ), dan terpantau kesehatannya. Memperbaiki gizi dan kesehatan ibu hamil merupakan cara terbaik dalam mengatasi kejadian stunting. Ibu hamil perlu mendapat makanan yang baik, sehingga apabila ibu hamil dalam keadaan sangat kurus atau telah mengalami Kurang Energi Kronis (KEK), maka perlu diberikan makanan tambahan kepada ibu hamil tersebut. Setiap ibu hamil perlu mendapat tablet tambah darah, minimal 90 tablet selama kehamilan. Kesehatan ibu harus tetap dijaga agar ibu tidak mengalami sakit. Kurang gizi pada masa pra-hamil dan ibu hamil berdampak pada lahirnya anak yang IUGR dan Berat Badan Lahir Rendah (BBLR). Kondisi IUGR hampir separuhnya terkait dengan status gizi ibu, yaitu berat badan (BB) ibu pra-hamil yang tidak sesuai dengan tinggi badan ibu atau bertubuh pendek, dan pertambahan berat badan selama kehamilannya. Pemenuhan zat gizi yang adekuat, baik gizi makro maupun gizi mikro sangat dibutuhkan untuk menghindari atau memperkecil risiko stunting (Mitra, 2015). Konsumsi ibu hamil dapat berupa makanan dan minuman yang mengandung zat energi, karbohidrat, protein dan lemak. Kebutuhan akan makronutrien selama kehamilan diperlukan akibat meningkatnya kebutuhan gizi ibu selama hamil untuk memenuhi perubahan metabolik, fisiologi selama kehamilan dan pertumbuhan janin di dalam kandungan. Energi merupakan sumber utama untuk mempertahankan berbagai fungsi tubuh seperti sirkulasi dan sintesa protein. Asupan protein selama kehamilan sangat diperlukan untuk proses pertumbuhan janin dan proses pertumbuhan janin dan proses embriogenesis agar bayi yang dilahirkan dapat dilahirkan dengan normal. Asupan protein yang kurang selama kehamilan dapat mengakibatkan gangguan pertumbuhan janin di dalam kandungan yang mengakibatkan bayi lahir dengan berat badan lahir rendah. Kekurangan nutrisi pada zat protein dan energi pada ibu hamil dapat mengurangi inti dari DNA dan RNA dan dapat mengganggu profil asam lemak sehingga transfer zat gizi ibu ke janin menjadi terganggu. Lemak memiliki peranan utama untuk menyediakan energi metabolik, hasil dari metabolisme lemak dapat berupa asam lemak. Asam lemak dibagi menjadi asam lemak jenuh dan asam lemak tak jenuh. Pertumbuhan janin di dalam kandungan membutuhkan asam lemak tak jenuh yang berguna untuk pertumbuhan dan perkembangan janin. Lemak memiliki peranan penting untuk pertumbuhan janin, jika janin memerlukan lemak maka akan ditransfer melalui plasenta. Bayi dengan berat badan lahir rendah mempunyai lemak yang lebih sedikit daripada bayi dengan berat badan lahir normal yang dalam hal ini disebabkan oleh gangguan transportasi 
lemak ke plasenta (MCAI, 2016). Pertumbuhan tidak optimal selama periode 1000 HPK memiliki dampak jangka panjang. Bila faktor eksternal tidak mendukung, pertumbuhan stunting dapat menjadi permanen sebagai remaja pendek. Tumbuh pendek seringkali dianggap sebagai pengaruh genetik, padahal faktor genetik hanya menjelaskan $15 \%$ variasi dibandingkan faktor gizi (Rahayu, 2014). Penelitian di Nepal menunjukkan bahwa bayi dengan berat lahir rendah mempunyai risiko yang lebih tinggi untuk menjadi stunting (Ni'mah, 2015). Masalah pertumbuhan stunting sering tidak disadari oleh masyarakat karena tidak adanya indikasi seperti penyakit.

Konsumsi makanan merupakan salah satu faktor yang secara langsung berhubungan dengan status gizi dan rendahnya konsumsi pangan atau kurang seimbangnya makanan yang dikonsumsi mengakibatkan terlambatnya pertumbuhan (Gluckman, 2005). Penelitian di Nusa Tenggara Timur menunjukkan bahwa peran ibu sebagai "gate keeper" dalam menjaga konsumsi dan status gizi rumah tangga terlihat sangat menonjol. Peran itu terlihat dari pengaruh pengetahuan gizi ibu, akses informasi gizi dan kesehatan, praktek gizi dan kesehatan ibu dan alokasi pengeluaran pangan dan non pangan (pendapatan). Dengan demikian pengetahuan yang dimiliki ibu tentang pemenuhan gizi sangat penting yang akan berdampak terhadap sikapnya (Picauly, 2013).

\section{DAFTAR PUSTAKA}

Azwar. (2010). Sikap Manusia Teori dan Pengukurannya, edisi 2. Cetakan XII. Yogyakarta: Pustaka Pelajar.

Dimiati H. (2012). Pertumbuhan Janin Terhambat sebagai Faktor Risiko Penyakit Kardiovaskular. Jurnal Kedokteran Syakiah Kuala,13(3), 157-64.

Dinkes Provinsi Sumatera Selatan. (2016). Gizi Kurang Penyebab Stunting. https://www.dinkes.sumseprov.go.id. Diunduh tanggal 4 Januari 2016.

Ernawati F, Rosmalina Y, Permanasari Y. (2013). Pengaruh Asupan Protein Ibu Hamil dan Panjang Badan Bayi Lahir terhadap Kejadian Stunting pada Anak Usia 12 Bulan di Kabupaten Bogor. Penelitian Gizi dan Makanan, 36(1), 1-11.

Goni, Loah, Pangemanan. (2013). Hubungan Pengetahuan dan Sikap Ibu Hamil dengan Status Gizi selama Kehamilan di Puskesmas Bahu Kota Manado, Ejurnal Keperawatan (e-Kp), 1(1).
Seseorang yang memiliki sikap baik terhadap gizi akan mempunyai kecenderungan berperilaku baik dalam memenuhi kebutuhan gizinya, begitupun sebaliknya. Sikap yang kurang terhadap perilaku pemenuhan kebutuhan gizi jika dimanifestasikan dalam bentuk perilaku akan menyebabkan asupan gizi yang kurang yang akan berkaitan dengan masalah kesehatan.

Penanggulangan masalah stunting harus dimulai dari sebelum anak dilahirkan dan bahkan sejak remaja untuk dapat memutus rantai stunting dalam siklus kehidupan. Namun demikian, sering kali perempuan tidak mengetahui kapan pastinya akan terjadinya kehamilan, maka persiapan kehamilan terutama tentang pemenuhan gizi perlu diketahui dan dilakukan sejak masa persiapan atau sebelum kehamilan sehingga pencegahan kejadian stunting dapat dilakukan lebih optimal.

\section{SIMPULAN}

Ibu yang mengikuti kelas ibu hamil, sebagian besar memiliki pengetahuan yang baik dan sikap yang postif. Terdapat hubungan yang bermakna antara pemberian kelas ibu hamil terhadap peningkatan pengetahuan dan sikap tentang pencegahan stunting.

Gluckman PD, Hanson, M.A. (2005). The Fetal Matrix: Evolution, Development and Disease. New York, United States: Cambridge University Press. http:// www.cambridge.org/9780521834575.

Hastuti PS, Nugroho HSW, Usnawati N. (2011). Efektifitas Pelatihan Kelas Ibu Hamil untuk Meningkatkan Pengetahuan, Sikap, Keterampilan dan Kunjungan Antenatal Care. Vorikes, 2(2), 122-34.

Kementerian Kesehatan RI. (2011). Pedoman Pelaksanaan Kelas Ibu Hamil. Jakarta: Kemenkes RI.

Millennium Challenge Account - Indonesia (MCAI). (2016). Stunting dan Masa Depan Indonesia.http://www.mcaindonesia.go.id. Diunduh tanggal 13 Oktober 2016.

Mitra. (2015). Permasalahan Anak Pendek (Stunting) dan Intervensi untuk Mencegah Terjadinya Stunting. Jurnal Kesehatan Komunitas, 2(6), 254-261. 
Ni'mah K., Nadhiroh SR. (2015). Faktor yang Berhubungan dengan Kejadian Stunting pada Balita. Media Gizi Indonesia, 10(1), 13-19.

Olsa EA., Sulastri D., Anas E. (2017). Hubungan Sikap dan Pengetahuan Ibu terhadap Kejadian Stunting pada Anak Baru Masuk Sekolah Dasar di Kecamatan Nanggalo. Jurnal Kesehatan Andalas, 6(3), 523-529.

Perignon, et al. (2014). Stunting, Poor Iron Status and Parasite Infection Are Significant Risk Factors for Lower Cognitive Performance in Cambodian School-Aged Children. Plos One, 9(11).

Pusat Data dan Informasi Kementerian Kesehatan RI. (2016). Situasi Balita Pendek. Jakarta : Pusat Data dan Informasi Kementerian Kesehatan RI.

Picauly, I dan Toy SM. (2013). Analisis Determinan dan Pengaruh Stunting terhadap Prestasi Belajar Anak Sekolah di Kupang dan Sumba Timur NTT. Jurnal Gizi dan Pangan, 8(1), 55-62.

Rahayu, Khairiyati. (2014). Risiko Pendidikan Ibu terhadap Kejadian Stunting pada Anak 6-23 Bulan. Penelitian Gizi Makanan, 37(2), 129-136.
Sartono. (2013). Hubungan Kurang Energi Kronis Ibu Hamil dengan Kejadian Stunting Pada Anak Usia 6-24 Bulan di Kota Yogyakarta. [Tesis]. Yogyakarta: Universitas Gajah Mada.

Syari M., Serudji J., Mariati U. (2015). Peran Asupan Zat Gizi Makronutrien Ibu Hamil terhadap Berat Badan Lahir Bayi di Kota Padang. Jurnal Kesehatan Andalas, 4(3), 729-736.

Trihardiani, Ismi. (2011). Faktor Risiko Kejjadian Berat badan Lahir Rendah Di Wilayah Kerja Puskesmas Kingkawang Timur dan Utara Kota Singkawang. [Skripsi]. Semarang: Program Studi Gizi Fakultas Kedokteran, Universitas Diponegoro.

Unicef Indonesia. (2012). Ringkasan kajian gizi ibu dan anak. Retrieved from http://www.unicef.or.id. Diunduh tanggal 13 Oktober 2016.

Wenas, RA., Lontaan, A., Korah, BH. (2014). Pengaruh Promosi Kesehatan tentang Tanda Bahaya Kehamilan terhadap Pengetahuan Ibu Hamil di Puskesmas Amurang Kabupaten Minahasa Selatan. Jurnal Ilmiah Bidan, 2(2), 1-5. 